\title{
Evidentiality and the expression of speaker's stance in Romance languages and German
}

Suggested citation referring to the original publication:

Discourse Studies 17 (2015) 2, pp. 182-209

DOI http://dx.doi.org/10.1177/1461445614564522

ISSN (print) 1461-4456

ISSN (online) 1461-7080

Postprint archived at the Institutional Repository of the Potsdam University in: Postprints der Universität Potsdam

Philosophische Reihe ; 138

ISSN 1866-8380

http://nbn-resolving.de/urn:nbn:de:kobv:517-opus4-404492 



\title{
Evidentiality and the expression of speaker's stance in Romance languages and German
}

\section{Gerda Haßler}

Universität Potsdam, Germany

\begin{abstract}
In recent years, the category of evidentiality has also come into use for the description of Romance languages and of German. This has been contingent on a change in its interpretation from a typological category to a semantic-pragmatic category, which allows an application to languages lacking specialised morphemes for the expression of evidentiality. We consider evidentiality to be a structural dimension of grammar, the values of which are expressed by types of constructions that code the source of information which a speaker imparts. If we look at the situation in Romance languages and in German, drawing a boundary between epistemic modality and evidentiality presents problems that are difficult to solve. Adding markers of the source of the speaker's knowledge often limits the degree of responsibility of the speaker for the content of the utterance. Evidential adverbs are a frequently used means of marking the source of the speaker's knowledge. The evidential meaning is generalised to marking any source of knowledge, what can be regarded as a result of a process of pragmaticalisation. The use of certain means which also carry out evidential markings can even contribute to the blurring of the different kinds of evidentiality. German also has modal verbs which in conjunction with the perfect tense of the verb have a predominantly evidential use (sollen and wollen). But even here the evidential marking is not without influence on the modality of the utterance. The Romance languages, however, do not have such specialised verbs for expressing evidentiality in certain contexts. To do this, they mark evidentiality - often context bound - by verb forms such as the conditional and the imperfect tense. This article shall contrast the different architectures used in expressing evidentiality in German and in the Romance languages.
\end{abstract}

\section{Keywords}

Adverbs, evidentiality, modal verbs, modality, pragmaticalisation

\section{Corresponding author:}

Gerda Haßler, Institut für Romanistik, Universität Potsdam, Leiterstraße I0, 14473 Potsdam, Germany.

Email: hassler@uni-potsdam.de 


\section{Introduction}

In recent years, the category of evidentiality has also come into use for the description of Romance languages and German. This has been contingent on a change in its interpretation from a typological category to a semantic-pragmatic category. Typologists assume that there is a universal inventory of grammatical and lexical categories, out of which each language makes a distinct selection. In about one-fourth of all of the languages of the world, the category of evidentiality is morphologically present (Aikhenvald, 2004: 1), that is, in every utterance the kind of source of the communicated knowledge must be indicated. With the assumption of the concept of evidentiality in pragmatic studies, it became possible to investigate the linguistic means of expressing the origin of the speaker's knowledge, which are not specialised in this function and not grammaticalised with this. In German and in the Romance languages, there are no specialised morphemes for the expression of evidentiality. However, there are grammatical and lexical means used for this purpose. Since these means belong to different levels of the language system and enter into different structural relationships, a comparison of the Romance languages and German promises to provide information about the different formative options of the semantic-pragmatic category of evidentiality. We therefore assume a broad conception of evidentiality and define it as a functional category as it is expressed by linguistic means that fulfil the function of indicating the source of information for the transmitted content of a certain proposition. In order to capture that evidential meanings range from lexical to grammatical functions, 'we speak of a "semantic-functional" domain here' (Diewald and Smirnova, 2010: 1). This semantic-functional understanding of evidentiality is necessary when studying evidentiality in Romance languages and German because the starting point for adducing evidential meanings in a language that does not possess real evidentials is the function rather than the form.

This article shall focus on the relationship between evidentiality and the expression of speaker's stance in Romance languages and German. By speaker's stance we understand linguistic and non-linguistic forms and strategies that show a speaker's commitment to the status of the information that he is providing. Stance-taking causes the speaker, among other things, to specify the sources of his knowledge, whether it be to give the utterance more weight or to reduce his own responsibility for the contents. In the first example, the speaker refers to his own reflections as the source of the content that is communicated; he thus marks the utterance evidentially and at the same time assumes responsibility for it:

(1) I think there is always going to be this element in business (British National Corpus (BNC), n.d., A6L 717)

In the second example, hearsay is named as the source of the communication. Through the evidential marking, it is said the speaker relinquishes responsibility for his statement:

(2) It is said that mentally handicapped people do not normally enjoy a happy life. (BNC, n.d., ANA 1212) 
As the examples show, evidentiality and the speaker's stance are inseparable in the reality of linguistic activities. It shall first be demonstrated that this fact lies in the nature of the considered categories and also applies to languages with genuine evidentials. Then, the category of evidentiality for languages without grammaticalised evidentials is to be determined analogous to the functional-semantic category of aspect, in order to treat overlaps and problems of distinguishing evidentiality from epistemic modality and within different kinds of modality. The comparison here will be multilateral, but it will refer to an onomasiological starting point, which we hope to find in the definition of evidentiality based on languages with grammaticalised evidentiality. We shall investigate whether in the various languages lexical or grammatical means are used to express evidentiality and how any identified structural differences affect the conformation of the speaker's stance. Finally, we shall discuss non-specific, covert forms of expression of evidentiality and shall attempt to explain their relation to speaker's stance.

\section{The determination of the category of evidentiality and speaker's stance}

With the definition of 'speaker's stance' as an indication of the speaker's commitment to the status of the information that he is providing, we have determined this category as central to a pragmatic study. Stance-taking indicates how the speaker's position with respect to a particular utterance is to be interpreted. At a basic level, stance can be expressed by contextualisation cues, culturally specific tools or resources for stancetaking. Stance-taking has to do with indexing one's orientation to the propositional content of discourse, to one's interactional partners or to conventional social identity categories. For the purpose of this article, we shall use the following definition of stance:

Stance is generally understood to have to do with the methods, linguistic and other, by which interactants create and signal relationships with the propositions they utter and with the people they interact with. (Johnstone, 2009: 30-31)

The concept of stance can be considered as 'a uniquely productive way of conceptualising the processes of indexicalisation that are the link between individual performance and social meaning' (Jaffe, 2009: 4). Stance is an emergent property of interaction which is not transparent in the linguistic form, but must be inferred from the empirical study of interactions in social and historical context.

There are different stances, which are shown by Alexandra Jaffe (2009) in her introduction to the book Stance: Sociolinguistic Perspectives (p. 7). Some of them are directly related to evidentiality, for example, the 'knowledge of, belief in or commitment to propositional content', called epistemic stance, or the 'claims to authority or responsibility', called assessment. If we draw a relationship, here, between stance and evidentiality, this of course assumes an overlapping of epistemic modality and evidentiality. Palmer (1986) refers to epistemic modality as an indication by the speaker of his '(lack of) commitment to the truth of the proposition expressed' and, in a broader sense, 
'as the degree of commitment by the speaker to what he says' (p. 51). Other authors define epistemic meaning as the speaker's confidence or lack of confidence in the truth of the proposition expressed in the utterance (Kärkkäinen, 2003: 18). Epistemic modality is thus the linguistic category that directly serves the expression of the speaker's stance. However, since the specification of the origin of the speaker's knowledge may also be connected to an indication of the attitude of the speaker as to the truth value of the utterance, epistemic modality and evidentiality may overlap.

Epistemic stance is likewise culturally grounded because it is embedded in particular regimes of knowledge and authority. Consequently, epistemic stance markers can be used to downgrade speaker authority and acknowledge other interactants' greater claims to hold relevant information (Rauniomaa, 2007: 232). Already Biber and Finegan (1989) have focused on evidentiality in their examination of textual features and clusters of stance markers as markers of text style.

To establish a relation of concomitance between stance and evidentiality, we need a broad notion of evidentiality that will be different from what typologists understand by evidentiality. But even the grammaticalised means of expression of evidentiality in languages with genuine evidentials can serve to express the speaker's stance. Let us consider the example of the Tuyuca, where one has to distinguish between the following kinds of evidentiality: (3a) the direct personal and visual experience of the speaker, (3b) the perception through hearing, (3c) making deductions from evidence, (3d) learning from the report of another person and (3e) drawing a conclusion based on logic (cf. Barnes, 1984):

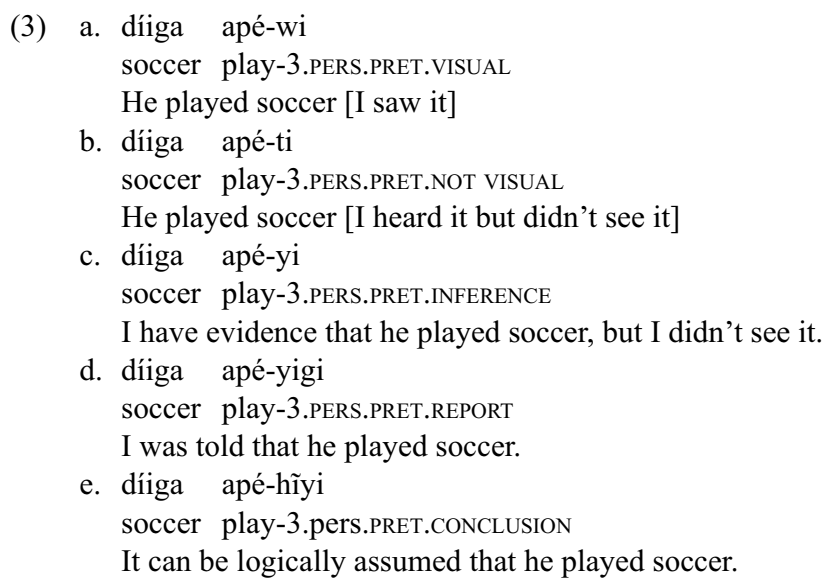

The simple assertion that someone played soccer is not possible here without providing the source of this knowledge. Cognitively, however, the own visual perception is more reliable than hearsay or the derivation of evidence. Thus, if a speaker uses the evidentiality marker $-t i$, he not only expresses that he has seen the action, but rather vouches more strongly for the truth value of the utterance than if he used the quotative -yigi.

Hence, evidentials as linguistic means with the primary characteristic of 'source of knowledge' do imply a direct reference to the certainty and responsibility of the speaker or the truth of his assertion. With the limitation to the pure evidentials, not only is the 
category of evidentiality inapplicable to European languages, it becomes problematic for everything that goes beyond the determination of elements with evidential core meaning. ${ }^{1}$

Evidential suffixes also characterise the caution with which a speaker handles the information. An example that evidential markers assume the pragmatic function of marking the insecurity of the speaker even in languages with pure evidentials is the use of the suffixes $-m i /-s h i /-c h i$ in the Huallaga dialect of the Quechua language, which allows the speaker to assume or reject responsibility for the content of what is said. With -mi the speaker assumes responsibility, with $-s h i$ he defers it to someone else and with -chi he indicates that no responsibility can be taken for this type of content.

According to Weber (1989), with (4a) the speaker expresses his certainty, with (4b) he refers to a report from someone else and with (4c) to a possibility:

(4) a. Wañu-nqa-paq-mi.

it will die [I assert that $]_{\text {evidential }}$

[I assert that] it will die.

b. Wañu-nqa-paq-shi.

it will die [I was told $]_{\text {evidential }}$

[I was told] it will die.

c. Wañu-nqa-paq-chi.

it will die [Perhaps $]_{\text {evidential }}$

[Perhaps] it will die. (p. 421)

The use of the signal evidentiality marker -shi goes far beyond the expression of second-hand information. It is also used in the so-called narrated past, for which one does not wish to assume responsibility. The Quechua culture places great value on avoiding gullibility, which the use of this evidential marker definitely reveals. A mixture of morphologically conceived evidentials with pragmatic circumstances seems apparent as soon as one goes beyond typological issues to look at the use of these elements. To examine evidentiality in the discourse, it is necessary to take the speaker's stance into account, even in languages with pure evidentials. Even more important is the interaction of these two categories in the pragmatic study of evidential discourse meanings in languages without genuine evidentials.

Nonetheless, we do not want to entirely detach the pragmatic oriented evidentiality concept from the typological concept. Operating with typological categories in differently defined contexts has been practised for some time. An example for the description of the category of evidentiality is the typological category of aspectuality, which is also used in the description of languages with verbs that do not have any grammaticalised means of expressing the quality of 'course of action'. In accordance with Bondarko, we assume that the aspect correlation 'perfective' versus 'imperfective', as is found in the Slavic languages ${ }^{2}$ and in Greek, forms the core of a functional-semantic category characterised as aspectuality (Figure 1).

On the periphery, several additional linguistic means, such as types of actions ('Aktionsarten') and adverbs, belong to aspectuality. In this sense, Bondarko (1984) considers it justified to assume a functional-semantic category of aspectuality even for languages lacking the grammatical core of aspectuality, the verbal aspect. The basis for this 


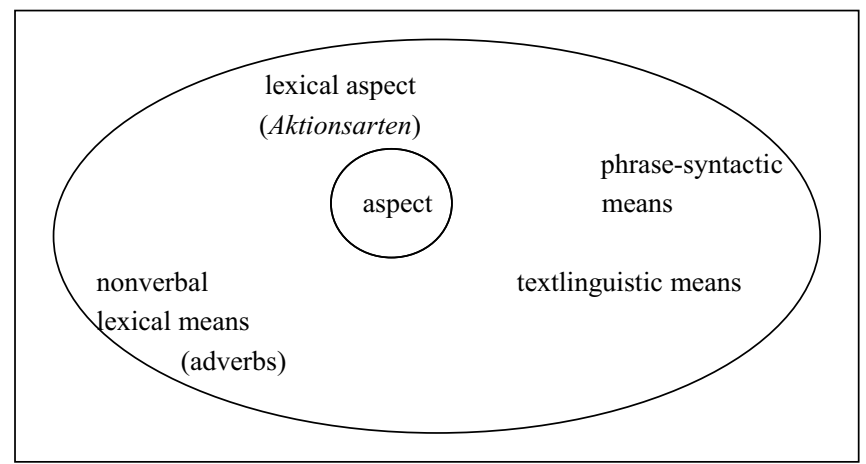

Figure I. Aspectuality.

transfer of a typological category to semantic and pragmatic circumstances is the assumption that there is a universal need for expression of the function taken over by the relevant category, which in languages lacking the grammatical core of the category can be assumed by other linguistic means, which thus have a greater diversity and can be polyfunctional.

We could generalise this view and apply it to evidentiality (Figure 2).

For the Romance languages and German, no linguistic means can be found which could be assigned to a core of evidentiality. Since there are not any forms of expression that would be grammaticalised with this function, the core would remain empty. However, other forms of expression could be assigned, which in certain contexts could take over evidential functions. Here, we mention a few, initially disordered examples. In the sequence of the enumeration we follow the usual designations of the kinds of typological evidentiality (cf. Barnes, 1984):

- Visual access marked by adverbs: Span. visiblemente 'visibly', Span. aparentemente 'apparently' and Span. evidentemente 'evidently, obviously' (and their equivalents in other Romance languages).

- Inference marked by modal verbs: Fr. Il doit l'avoir fait par pitié. 'He must have done it out of pity'.

- Inference marked by analytic future which also expresses epistemic modality: Germ. Die Sekretärin wird krank sein. 'The secretary will be ill' (because she is not here).

- Information by others: (journalistic) conditional: Span. El general Díaz Alegría se habría trasladado a París.

- Information by others/hearsay: evidential locutions: It. Si dice che la quotazione in Italia sia propedeutica a nuove acquisizioni. 'It is said that having quotas in Italy paves the way for new achievements'.

- Hearsay marked by German modal verbs wollen and sollen: Maria soll ein Buch geschrieben haben. 'I heard that Maria wrote a book'. Maria will ein Buch geschrieben haben. 'Maria claims to have written a book'. 


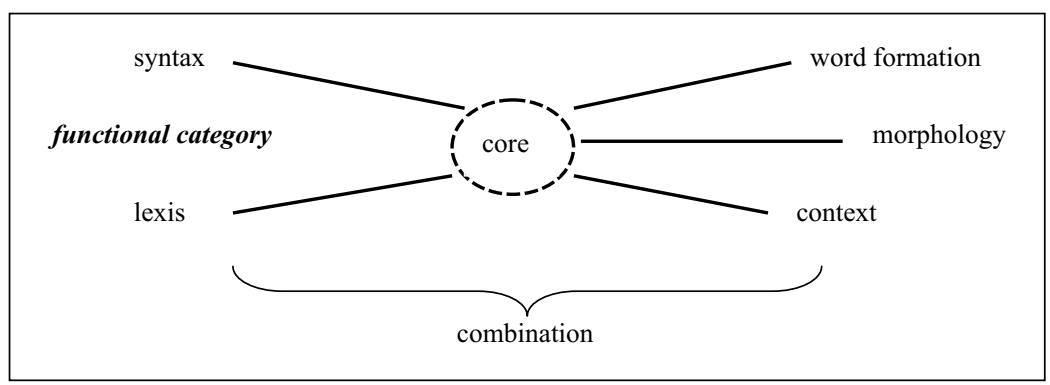

Figure 2. Evidentiality.

In this sense, we consider evidentiality to be a structural dimension of grammar, the values of which are expressed by types of constructions that code the source of information which a speaker imparts. Usually we differentiate between direct and indirect evidentiality (Figure 3; cf. Willett, 1988: 57).

Direct evidential expressions are used by the speaker when he himself (visually, auditorily or through other senses) has perceived the occurrence about which he reports in his evidentially marked utterance (cf. De Haan, 2001: 203). In this case, the described circumstance has taken place within the deictic sphere of the speaker (cf. De Haan, 2005: 2). Indirect evidential expressions come into use when the speaker did not perceive the occurrence himself, but was informed of it by others. If the speaker therefore uses indirect evidential markings, the circumstance expressed by him took place outside of his deictic sphere (cf. De Haan, 2005: 2). If the represented circumstance is a conclusion, and if this is characterised as such, we refer to this as using inferential markers.

\section{Commonalities and demarcation problems in the marking of speaker's stance and different types of evidentiality}

If we look at the situation in Romance languages ${ }^{3}$ and in German, drawing a boundary between speaker's stance, epistemic modality and evidentiality presents problems that are difficult to solve. Even if we assume that there are linguistic elements which fulfil the original function of marking the source of the speaker's knowledge, this is contingent with the marking of the speaker's stance and epistemic modality. This can be seen in the German adverb offensichtlich 'apparently', which with its lexical meaning refers to immediate visibility. Example (5), however, does not refer to a process simply seen with one's own eyes but rather to a conclusion drawn from complex observations or something that the journalist may have learned from the company. Offensichtlich can thus express inferential and quotative evidentiality in addition to direct visual evidentiality:

(5) Das schnelle Wachstum des Internet-Auktionshauses Ebay hat offensichtlich weitreichende technische Probleme zur Folge. (Source: spiegel.de vom 03.01.2005)

The rapid growth of the Internet auction house Ebay has apparently led to far-reaching technical problems. 


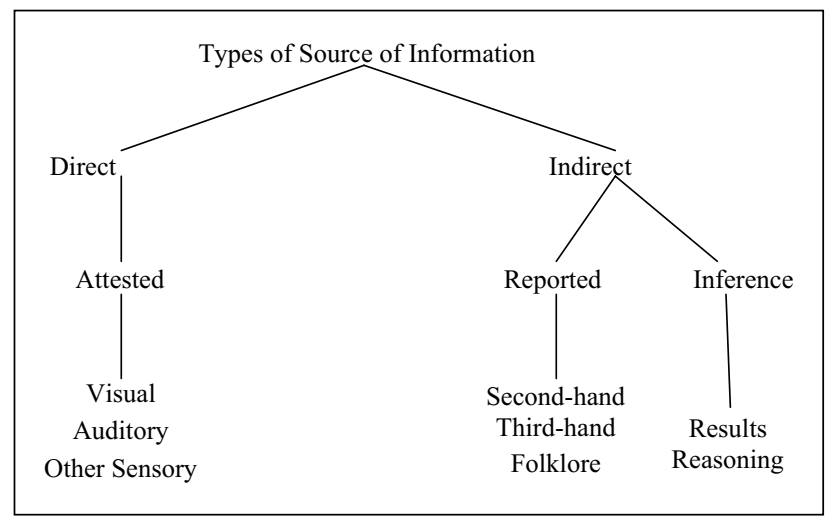

Figure 3. Willett 1988:57.

Without offensichtlich the sentence would doubtlessly be more definite than with the adverb, which based on its original lexical meaning would have to underscore the obviousness of the conclusion. Due to frequent use, the definition of offensichtlich has undergone a change, which enables its use for indirect evidentiality. With the use of offensichtlich as evidential marking, the author even infers an epistemic modalisation as 'very probable' and expresses his attitude towards the conveyed content, which however is less binding than without the evidential marking. Still greater indefiniteness is expressed in sentence (6), in which a generally applicable statement which encompasses the future is weakened with the word offensichtlich:

(6) Das macht die Quellenlage offensichtlich unanfechtbar. (Source: berlinonline.de from 14 January 2005)

That makes the source material apparently indisputable.

The lexical meaning of offensichtlich must have undergone changes for it to be used as the modalisation of an event that may be seen as only hypothetical. As adverb, offensichtlich can only partially take on the meaning of the adjective in ein offensichtlicher Irrtum ('an obvious error'). As adjective, offensichtlich means 'what comes about with direct necessity and without any possibility of doubt on the level of interpretation or judgement', while in adverbial usage the characteristics 'direct visibility of the proof' and 'exclusion of error' have diminished in importance. Offensichtlich is a sentence adverb which is used in the two examples (5) and (6). Basically, the adverb used in this way contains an additional predicate and could be transformed into a main clause, in which the sentence in which it stands contains the argument:

(5') Es ist offensichtlich, dass das schnelle Wachstum des Internet-Auktionshauses Ebay weitreichende technische Probleme zur Folge hat.

It is apparent that the rapid growth of the Internet auction house Ebay has led to farreaching technical problems. 
(6') Es ist offensichtlich, dass die Quellenlage unanfechtbar ist.

It is apparent that the source material is indisputable.

While with the explication of the predication with the predicate adjective the author makes a clear statement about the plausibility of his conclusion, with the adverb he merely marks the conclusion as such. No explicit reference is made to what was behind it or its basis. The use of the adverb offensichtlich allows the tuning out of the sources of the reported knowledge; however, the existence of such sources is not called into question. Thus, a certain vagueness of the assertion is accomplished which the text producer does not have to commit himself to or specify. The limitation of the regress obligation, however, takes place through the evidential marking of the statement, which is concluded from bases and sources of knowledge which are not specified more closely.

The other German evidential adverbs, for example, offenkundig ('evidently', 'obviously'), anscheinend ('seemingly'), wie es scheint ('as it seems'), offenbar ('clearly', 'evidently') and augenfällig ('as is particularly evident'), behave quite similarly and have to a great extent lost the reference to visual evidentiality that underlies them etymologically. We shall therefore limit ourselves to the syntactic analysis of offensichtlich. The flexibility of its position in the sentence can be an argument that it is a marker of epistemic modality. As an adverb, offensichtlich can take any position in the sentence. In the corpus of the Digital Dictionary of the German Language (DWDS; http://www.dwds. $\mathrm{de} /$ ), it is primarily found in the sentence often in a position following the verb and at the beginning of a sentence:

(7) Dem Wal gefiel offensichtlich, was ich tat. (DWDS, Moers, Walter, Die 13 1/2 Leben des Käpt'n Blaubär, Frankfurt a.M.: Eichborn 1999, 69)

The whale apparently liked what I was doing. (DWDS, Moers, Walter, The 13 1/2 Lives of Captain Bluebear, Frankfurt a.M.: Eichborn 1999, 69)

(8) Beim Bundesparteitag in Hamburg saß ein Mann auf dem Podium, der offensichtlich antisemitische und rechtsradikale Ansichten hegt. (DWDS, Die Zeit, 9 July 2009)

At the national convention of the party in Hamburg a man sat on the podium who obviously holds anti-Semitic and radical right-wing views. (DWDS, Die Zeit, 9 July 2009)

(9) Offensichtlich gibt es aber noch eine zweite Information, die man bisher im Zusammenhang mit dem Test nicht öffentlich machte. (DWDS, Die Zeit, 5 July 2009)

However, there is apparently yet a second information, which to date has not been made public in connection with the test. (DWDS, Die Zeit, 5 July 2009)

But offensichtlich can also stand at the end of an utterance:

(10) Doch anstatt dies als Warnung zu betrachten und die eigenen Bilanzen kritisch zu prüfen, drohten die Banken der Regierung mit Klagen und versuchten zu handeln. Erfolgreich offensichtlich. (DWDS, Die Zeit, 5 July 2009)

But rather than looking at this as a warning and critically examining their own balance sheets, the banks threatened the government with lawsuits and attempted to negotiate. With success apparently. (DWDS, Die Zeit, 5 July 2009) 
In a similar way, this applies to the Spanish adverbs visiblemente 'visibly', aparentemente 'apparently' and evidentemente 'evidently, obviously', which in their direct meaning denote visual access to the content of the proposition. However, while this access for visiblemente is explicit (11), aparentemente and evidentemente can also denote conclusions which are not based on visual perception, but on hearsay (12) or inference (13) (cf. Haßler, 2004):

(11) La suma de estos quebrantos - que se hizo evidente cuando el gobierno debió renegociar su gigantesca deuda externa - ya obligó al Presidente Figueiredo a someterse a una delicada operación de by-pass y lo ha afectado visiblemente en lo físico. (Hoy, 25 April1 May 1984)

The sum of these losses, which became evident when the government had to renegotiate its gigantic foreign debt, had already compelled President Figueiredo to undergo a serious by-pass operation and had visibly affected him physically. (Hoy, 25 April-1 May 1984)

(12) Esta confianza estaba evidentemente fundada en la disposición general de todos los españoles, que guiados por el instinto de la felicidad, que el autor de la naturaleza puso en el corazón de los hombres, sabían que no había otro camino para que se mejorase la suerte de la España, que el de cambiar las instituciones, ni otro medio de conseguirlo que por un alzamiento militar. (El Imparcial, 1 February 1822)

This trust was evidently based on the general disposition of all Spaniards who - guided by the instinct of happiness which the creator of nature has placed in the human heart - knew that there was no other way for the fate of Spain to turn positively than to change the institutions, and there was no other means to achieve that than by a military uprising.

(13) Y, de igual manera que en el Estado jurídico se destacan lazos legislativos que descubren y ordenan las relaciones en todo el ámbito nacional, porque a todos protegen y a todos obligan las relaciones aparentemente invisibles de la colectividad, de la misma manera en el ámbito económico nacional hay que descubrir también las interrelaciones económicas entre los distintos sectores, [...]. (Contabilidad Nacional, ABC, 11 July 1958)

And in the same way that in the lawful state legislative ties dominate which uncover and organise the relationships on the entire national level because they protect everyone and oblige everyone to uphold the apparently invisible relationships of the group, in the same way on the national economic level one must also uncover the economic interrelationships between the different sectors [...].

As example (13) shows, aparentemente is readily combinable with elements which negate the visibleness (aparentemente invisibles).

In example (14), aparentemente is used autonymically in an oral interview and indicates the process of becoming conscious of its use. At first, the speaker uses it formulaically (David es un niño supernormal, aparentemente) after which she becomes aware that her speech act is not a conclusion, but a simple statement. For this reason, she corrects herself with words such as bueno, aparentemente $y$ sin aparentemente and es supernormal:

(14) El segundo se llama David. David es un niño supernormal, aparentemente, bueno, aparentemente y sin aparentemente, es supernormal y tiene ahora pues yo creo que 
veintiséis veinticinco, bueno, nunca me aclaro con estos dos. (1998, Entrevista CSC008, mujer, 20 años, fragmentos no transcritos en el Corpus para el estudio del español)

The second one is named David. David is apparently a supernormal child, well, apparently and not apparently, he is supernormal, and now I think he's twenty-six or twenty-five, I'm not sure which of the two. (1998, Entrevista CSC008, woman, aged 20 years, untranscribed fragments in the text body)

The data from the French corpus Frantext also confirm this usage of evidential adverbs, whereby apparemment in particular is also used increasingly within a narrow scope, that is, with modalising or limiting function only with reference to a word or a part of the sentence. In the following sentence, apparemment refers to the property of superiority to be decisive and thus marks this quality as conclusions or coming from hearsay. The doubting context (I never understood the nature ...) also suggests that a modalisation is not very probable here:

(15) [...] je n'ai jamais bien compris la nature de cette supériorité apparemment decisive (Frantext, n.d., R210 - Genette, Gérard, Bardadrac, 2006, 308)

[...] I never understood the nature of this apparently decisive superiority (Frantext, n.d., R210 - Genette, Gérard, Bardadrac, 2006, 308)

None of the above examples from (11) to (15) aim to state visible facts, but rather to convey conclusions. The evidential meaning of the adverb has clearly shifted from characterising visually observable phenomena to conveying one's own conclusions. Inferential evidentiality and epistemic modality are expressed by these adverbs in equal measure. Besides this, by means of the adverbs, the speaker subjectifies his statement and conveys his stance.

It seems possible in these cases to speak of a lexical meaning that is ultimately based on the fact that always whenever the speaker seems motivated to explicate evidence, a reduction in the degree of evidentiality takes place as well. It is not that the content of the utterance is apparent, not that it is visible, but rather the non-presence, the not-mentioning of the information source which is decisive for the use of the adverbs.

At the same time, these examples show that the marking of evidentiality cannot be separated from the subjectification of the utterance, its relativisation to the epistemic centre of the speaker and thus the expression of speaker's stance. It seems once again confirmed that the speaker's perspective is a superordinate category, which includes several overlapping subcategories (Figure 4; Hennemann, 2013: 419, Simon-Vandenbergen and Aijmer, 2007).

\section{Modal verbs and verb forms in the marking of evidential value}

While we were able to note a broadly similar behaviour in the Romance languages and German for the adverbs, there are considerable differences in the modal verbs and verb forms in the marking of the evidential value of 'information by others/hearsay'. Whereas in the Romance languages the conditional and especially the indicative forms of the imperfect are refunctionalised for this purpose, in German deontic modal verbs are 


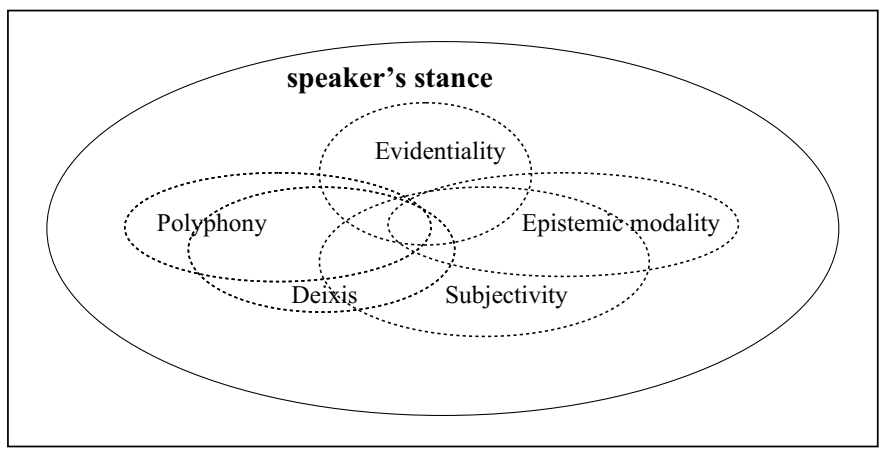

Figure 4. Speaker's stance.

evidence for the overlap of epistemic modality and evidentiality. First, we will look at the German verbs sollen and wollen and then turn to the indicative verb forms as expression of evidentiality.

\section{Deontic modal verbs and evidentiality}

The modal verbs sollen and wollen not only occur as expression of deontic and buletic modality, they can also be used with evidential values:

(16) Jan soll seine Hausaufgaben machen. deontic (epistemic reading possible) Jan should do his homework.

(17) Anna will ein Bier trinken. buletic Anna wants to drink a beer.

(18) Jan soll seine Hausaufgaben gemacht haben. Jan is said to have done his homework.

(19) Anna will ein Bier getrunken haben. Anna claims to have drunk a beer.

evidential (information: 3rd person),

evidential (information: subject)

In sentence (18), the fact that Peter did his homework is presented as learned from a third person and accurate with medium probability, while the speaker in sentence (19) has the information from the person appearing as subject, but this information is presented as only somewhat probable. The trigger for the clearly evidential reading in both sentences is the perfect form of the main verb. For sollen in connection with the present form (cf. (16)), the deontic reading is preferred, but the epistemic reading is not excluded, while for wollen in the context of the present tense only the buletic meaning is possible (17).

Let us now consider the evidential meaning of wollen and sollen in journalistic texts and their possibilities of expression in Romance languages. The following quotation shows that the form will can without any problems mark the information communicated by a foreign source, namely, from the person being talked about: 
(20) Anders Behring Breivik hatte am Samstag die Täterschaft bei beiden Anschlägen zugegeben. Er will sie allein ausgeführt haben. Am Freitag hatte er im Osloer Zentrum erst eine Autobombe explodieren lassen, die mindestens sieben Menschen tötete. (http://www. sueddeutsche.de/politik/bluttat-in-norwegen-attentaeter-nennt-anschlaege-grausam-abernotwendig-1.1123955)

Anders Behring Breivik had admitted the perpetration of both attacks on Saturday. He claims to have done it alone. Previously on Friday he set off an explosion of a car bomb in the centre of Oslo, which killed at least seven people.

At the same time, a distance of the producer of the utterance is expressed, which makes its contents appear to be rather unlikely. Also with sollen, which refers to a source that is not identical with the subject and with the speaker, the regress obligation of the text producer is relativised, making the statement more probable:

(21) Behring Breivik soll ausdrücklich versichert haben, allein gehandelt zu haben. Doch stößt diese Darstellung bei den Behörden auf Skepsis. Die Ermittler gingen eigenen Angaben zufolge unter Hochdruck Hinweisen auf einen zweiten Schützen nach, der an dem Blutbad auf der Insel beteiligt gewesen sein könnte. (http:/www.stern.de/ panorama/doppelanschlag-in-norwegen-attentaeter-streitet-strafbare-handlung-ab1709391.html)

Behring Breivik is said to have given explicit assurances that he acted alone. However, this representation has been met with scepticism by the authorities. According to their own report, under high pressure the investigators are following up clues of a second shooter who might have been involved in the massacre on the island.

An important structural difference between the Romance languages and German is that in these languages no corresponding polyfunctional modal verb is available that could take on evidential meaning in corresponding contexts - for example, with the main verb in the perfect tense. The expression of the origin of knowledge of the text producer of a mentioned subject must take place here more explicitly, as in the French example (22) through the performative formula a reconnu les faits ('he admitted the facts') and through quotation marks marking direct quotes:

(22) $[\ldots]$ depuis son arrestation vendredi, Behring Breivik a reconnu les faits, estimant que les attaques étaient « cruelles » mais « nécessaires ». Il a également affirmé avoir « agi seul » (http://tempsreel.nouvelobs.com/actualite/monde/20110723.OBS7523/norvegeanders-behring-breivik-profil-d-un-tueur-presume.html)

[...] since his arrest on Friday Behring Breivik has acknowledged the facts and assessed that the attacks were 'cruel', but 'necessary'. He also stated that he had 'acted alone'.

In example (23), the information source, l'agence de presse norvégienne 'the Norwegian press agency', is named explicitly. This explicit marking takes place in the example alongside the use of the journalistic conditional, which is frequently used for quotative evidentiality, but also for conclusions: 
(23) Les enquêteurs penchent donc pour le moment pour un acte isolé, mais ils n'excluent pas des complicités. Selon l'agence de presse norvégienne, ils seraient d'ailleurs à la recherched'un2etireurpotentiel.(http://www.lefigaro.fr/international/2011/07/23/0100320110723ARTFIG00418-un-homme-obsede-par-le-multiculturalisme.php)

At the moment, the investigators tend to regard this as an isolated act, but they do not rule out accomplices. According to the Norwegian news agency, they are also looking for a second potential shooter.

In the Spanish example (24), an evidential marking with oficialmente se dice corresponds to the German sollen:

(24) Aunque oficialmente se dice que Anders Behring Breivik actuó en solitario, las investigaciones policiales van dirigidas a destapar qué hay o quien está detrás de estos dos atentados, y a no dejar el menor rastro de duda sobre si el detenido ha contado con la ayuda de más manos ejecutoras. De momento nada ha trascendido sobre el móvil y los cómplices.(http://www.Ine.es/internacional/2011/07/24/detenido-anders-behring-breivikultra-pertenecio-segundo-partido-pais/1106842.html)

Although it is officially supposed that Anders Behring Breivik acted alone, police investigations are still seeking to determine what or who is behind these two attacks, and they are not leaving the slightest trace of a doubt whether the prisoner could have had help from others in carrying out the deed.

In addition, the use of performative verbs (reconocer) in connection with the immediate designation of the source of information provides evidential information and contributes at the same time to reducing the regress obligation of the current speaker or writer:

(25) Los investigadores consideran a este hombre como el autor de los dos ataques, la explosión de una bomba en el centro de Oslo y la masacre cometida luego en la isla de Utoya, cerca de la capital, indicó Andresen en una rueda de prensa. El sospechoso reconoció que disparó en la isla, declaró el comisario Sveinung Sponheim. (http://www. latribuna.hn/2011/07/24/sospechoso-de-ataques-de-oslo-admitio-responsabilidad/)

The investigators consider this man to be the perpetrator of these two attacks, the explosion of a bomb in the centre of Oslo and afterwards of the massacre on the island of Utøya, near the capital city, Andresen announced to the press. The suspect admitted that he had shot on the island, Commissar Sveinung Sponheim said.

While in German the simultaneous evidentialisation and stance-taking - probable to a small or medium extent - take place via the verbs wollen and sollen, in the Romance languages this information must be expressed more explicitly via lexical elements. By contrast, when marking a high degree of probability and simultaneous indication of the origin of the knowledge from conclusion, appropriate modal verbs are available both in the Romance languages and in German. In examples (26) to (30), the corresponding forms of müssen, devoir, deber, dever and dovere express evidential conclusions which are modally attributed a high probability: 
(26) An einem einzigen Tag hat Anders Behring Breivik 77 Menschen kaltblütig ermordet. Allein die Monstrosität seiner Verbrechen mag manchen zu der Überzeugung bringen, dass der 33-Jährige geisteskrank sein muss. (http://www.sueddeutsche.de/panorama/ urteilsbegruendung-im-fall-breivik-ein-terrorist-mit-extremistischem-weltbild-1.1449230)

On a single day Anders Behring Breivik killed 77 people in cold blood. Alone the monstrosity of his crimes may induce some people to believe that the 33 -year-old must be insane.

(27) Dans ce cas subsidiaire, « il n'y a aucun doute que Breivik doit recevoir la peine la plus sévère, 21 ans de rétention de sûreté » (http://www.charentelibre.fr/2012/06/21/tuerie-doslo-le-parquet-requiert-l-internement-psychiatrique-de-breivik,1101669.php)

In this subsidiary case 'there is absolutely no doubt that Breivik must receive the strictest punishment, 21 years in a high-security prison'.

(28) Noruegos, es una verguenza su justicia. 77 vidas perdidas entre 21 anos. No sean ridiculos reformen sus leyes. Este asesino debe estar planificando su segundo golpe cuando salga. (http://es-us.noticias.yahoo.com/breivik-declarado-responsable-actos-condenado-21$\mathrm{a} \% \mathrm{C} 3 \% \mathrm{~B} 1$ os-c\%C3\%A1rcel-081835128.html)

Norway: its criminal justice system is a disgrace. 77 lives lost who were under 21 years of age. They need to reform their laws in order not to appear ridiculous. This murderer must already be planning his second attack for when he is released.

(29) O veredicto de Anders Behring Breivik, o autor ataque no verão passado na Noruega, deve ser conhecido ou a 20 de julho ou a 24 de agosto, anunciou, hoje, o Tribunal de Oslo. (http://www.aeiou.pt/quiosque/policia-diz-que-breivik-nao-teve-cumplices)

The verdict against Anders Behring Breivik, the perpetrator of the attack which took place in Norway last summer, is supposed to be read on July 20th or August 24th, the court in Oslo announced today.

(30) Se un individuo può arrivare a considerare di nessun valore la vita di un altro essere umano, tanto da premeditarne la morte per propria mano, allora deve esserci qualche cosa chenonvanellasuamente.(http://www.giornalettismo.com/archives/463821/cosa-insegnail-caso-breivik/)

If an individual can come as far that he considers the life of another human to be worthless, and he thus plans this person's death by his own hand, something must be wrong inside his head.

There are additional verbs, for example, werden, drohen, versprechen and scheinen, which in certain contexts can take on an evidential meaning. Diewald and Smirnova (2010) describe the verbs in the following sentences as evidential expressions of direct evidentiality:

(31) a. Der Wasserspiegel wird steigen.

The water level is bound to rise.

b. Der Wasserspiegel droht zu steigen.

The water level threatens to rise.

c. Der Wasserspiegel verspricht zu steigen.

The water level promises to rise. 
d. Der Wasserspiegel scheint zu steigen.

The water level seems to rise. (pp. 41-42)

For them, these constructions "constitute the grammatical core of evidentials in German, i.e. the automatized, routinized, backgrounded method of expressing evidential distinctions in German' (Diewald and Smirnova (2010: 42). As we have seen, not only direct evidentiality but also the reportive branch of the indirect evidentiality uses verbs (sollen, wollen). The expression of evidentiality in German thus appears to be based primarily on verbs with an altered meaning. We understand here under altered meaning the inclusion of additional evidential properties in the modal verbs (cf. (18), (19)) as well as the possibility not to use the verbs threaten and promise with human subjects, but rather to use them in the context of observable processes ((31b), (31c)).

Nevertheless, it is difficult to consider these verbs as a core category of evidentiality. On the one hand, they are semantically too heterogeneous; on the other hand, they cannot be considered as grammatical means of evidentiality. I would like to illustrate this using the example of the verb drohen 'threaten', which originally was a verb announcing a future action which is negative for the hearer. In this meaning, only humans come into question as subjects:

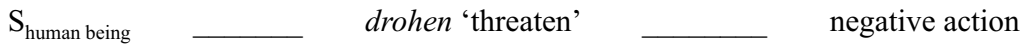

(32) Französische Arbeiter drohen mit Werks-Sprengung. (DWDS, Die Zeit, 13 July 2009) French workers threaten to blow up factory.

(33) Als der sich weigerte, drohte der Papst, ihn vom Gerüst hinunterwerfen zu lassen. (DWDS, Schwanitz, Dietrich, Bildung, Frankfurt a.M.: Eichborn 1999, 98) When he refused, the pope threatened to have him thrown down from the scaffolding.

In the evidential meaning, drohen is used when the subject does not appear as the producer of an utterance announcing a negative action, but as potential patient of this act, as in the following sentence die Schweiz (Switzerland):

(34) Eine Zeit lang drohte die Schweiz zum europäischen Umschlagplatz für Nazigerümpel zu verkommen. (DWDS, Die Zeit, 10 July 2009, Nr. 29)

For a long time Switzerland threatened to degenerate into a hub for Nazi junk.

The use is even more clearly evidential if objects, abstractions or processes occur as subjects:

(35) Die Wand droht einzustürzen.

The wall threatens to fall.

(36) In dem Pendelschlag der Kulturgeschichte kehren immer Zeiten wieder, wo in dieser Hinsicht wirklich ein Tiefstand droht, das Seil ganz nahe am Boden schleift und der Leib in seinem Rock zu degenerieren beginnt. (DWDS, Bölsche, Wilhelm: Das Liebesleben in der Natur. Bd. 3. Leipzig, 1903) 
In the pendulum of cultural history times recur again and again where in this respect there threatens to be a real low, the rope drags quite close to the ground and the body begins to degenerate in its coat.

(37) Ihm drohen zwei Jahre Sperre. (DWDS, Die Zeit, 13 July 2009)

He faces being barred for two years.

Nevertheless, the evidential meaning of the conclusion from direct observation or knowledge of the facts is always connected to the announcement of a negative consequence. A sentence like (38) is not excluded, but it would be taken as ironic:

(38) Er droht schon wieder den Preis zu gewinnen.

He threatens to win the prize again.

Because of this semantic restriction and the resulting contextual constraint, a grammaticalisation of drohen cannot be assumed as a core of evidentiality.

\section{Indicative verb forms as expression of modality}

The lack of the evidential meaning of certain modal verbs is compensated in the Romance languages in various ways, among other things through a covert expression of modality through indicative imperfect verb forms (cf. Haßler, 2012).

Like Fernández Ramírez (1986), García Fernández (2004: 90ff) uses the term imperfectos modalizados ('modalised imperfects'), by which he means 'una serie de usos del imperfecto etiquetados de diferentes maneras cuyo denominador común es el de la modalización' ('a series of different uses of the imperfect that are labeled differently and the common denominator of which is the modalisation', García Fernández, 2004: 90). In fact, in its 'non-typical' use, the imperfect can convey non-factuality and counter-factuality. Non-factual utterances are those in which the speaker makes no statement about the veracity of the utterance; in counter-factual utterances, the narrator negates this veracity. In the following example, the business deal is by no means concluded. On the contrary, closure of the deal is declared to be impossible because a condition is lacking:

(39) Si yo pudiera, mocito, este trato se cerraba if I could, fellow, this deal REFL close.3.S.IPFV

If I could, fellow, this deal would be closed. (García Lorca, Poesía Española, Antología por Gerardo Diego, 313)

The function of the English modal verb would is assumed in the Spanish sentence by the imperfect. In examples like (39) the conditional construction provides a context for the interpretation of the imperfect as irrealis. However, the use of the imperfect is different in the following sentence from language used in the press:

(40) Peres reconocía ayer que el presidente sirio, Hafez El Assad, será el gran ausente de la cumbre, si bien ha sido informado por Mubarak de todos los detalles. 
Peres acknowledged (IPFv) yesterday that the Syrian president, Hafez El Assad, would be the 'great absentee' at the summit, although he was informed by Mubarak about all the details. (La Vanguardia, 2 February 1995, Política)

In this case, the use of the imperfect appears to contradict all prototypical characteristics: what is reported here is a singular, temporally localised and completed utterance by Peres. This would seem to call for the use of the simple perfect, like in example (41):

(41) Juppé reconoció ayer que los ingresos fiscales 'están en una auténtica situación de siniestro', al no haberse cumplido las previsiones de crecimiento.

Juppé acknowledged.PRF yesterday that tax revenues are 'in a really disastrous situation', since the growth forecasts were not fulfilled. (La Vanguardia, 30 September 1995, Economía y Hacienda)

Why does not the example in (40) meet our expectations in terms of the 'prototypical' use of the verb? This is a report about a unique and completed statement by Peres, for which - like the example (41) in the report about the statement by Juppé - a perfective verb form (reconoció) would be expected. The opposition of the perfective and imperfective verb form is not without function. Rather, with the use of the Spanish imperfecto a subjective nuance can be introduced into the text, which also includes the possibility of referring to a vague and unspecified source. The use of the imperfect in journalistic texts has to do with the reduction in the recourse obligation of the journalist, that is, the extent to which he or she takes responsibility for the written content. The use of the imperfect arises here from the evidentiality as means of bringing forth the fact that the content of the utterance is taken from a source. In this case, contextual elements are not available for the expression of modality or evidentiality. Here evidentiality is covert in the sense that no specific means are used for their expression, but rather that it uses a different form from the one that is expected. When we speak here of covert evidentiality, this of course does not mean that any lack of overt means of expression can be interpreted as the presence of a functional category. In this case, any category could be postulated and demonstrated by the lack of means of expression. Under covert evidentiality, we understand rather that an evidential meaning is attached to a form that has a contiguous meaning, which to a certain extent is 'hidden under it'.

While in the example (41) the acknowledgement is simply stated as a fact, the use of the imperfecto in journalistic texts reduces the regress obligation of the journalist and therefore has to do with stance-taking. Since this form of modalisation has to do with the expression of the origin of information from a foreign, undetermined source, the German translation with soll as used evidentially seems justified, but it would be a very strong, overt marking of evidentiality. Due to the lack of aspectual markings in German, however, the difference between the perfective reconoció and the imperfective reconocía is often not taken into account.

The imperfect has thus evolved into a verb form that can be described as undetermined, unfinished and regularly characterising the textual background. There are different explanations for its modal use. The statement reiterated in linguistic research that past tense forms tend to be used modally (e.g. Comrie, 1976; Coseriu, 1976; Dessì Schmid, 2010; Detges, 2001; Fleischmann, 1982; Reyes, 1990) must, however, be 
tempered by examples like the following, in which the imperfect does not refer to the past:

(42) Si tu étais ici, quel bonheur. If you were here, what a joy.

$(\rightarrow$ present $)$

(43) Il serait heureux s'il réussissait à son examen. $(\rightarrow$ future $)$ He would be lucky if he passed the exam.

More plausible seems the relationship of aspectual features of the verb form with the ability of modal and evidential uses. ${ }^{4}$ In addition, the lack of some polyfunctional modal verbs (e.g. for 'want') in Romance languages coincides with the typological thesis 'In the absence of modal verbs, aspect fills the expressive gap' (Abraham and Leiss, 2008: XIV). But above all, the use of modalised imperfect verb forms can be interpreted as a metonymic process starting from the aspectual meaning. The indeterminacy, the unfinished nature of the process shown and its standing in the textual background - that is, the features of imperfective aspectuality - form the bridge to epistemic modality.

By using the imperfect past tense, the speaker makes a very economical decision. The encyclopaedic knowledge of the speaker concerning the fact that something which is indefinite in its beginning and end therefore has a lesser degree of assertiveness or applies only under certain conditions enables the transmission to the expression of stance. Therefore, in the following sentence, the imperfecto (podias) is used in the irrealis construction for the conditional:

(44) Si hubiese otra taberna abierta a estas horas, te podias despedir de mi como cliente. (I. Aldecoa, En el kilómetro 400, en Libro de Lecturas, 37. vgl. Fernández Ramírez, 1986: 276)

If another tavern were open at this hour, you could say good-bye to me as a customer.

In some types of text, particularly in journalistic language, the reference of regress obligation for the content of the utterance to another person or source is especially important, and this is regularly achieved with the imperfect past tense. ${ }^{5}$ There are gradual differences between the various Romance languages. In French this function is primarily assumed by the quite extensive use of the conditionnel journalistique (Raible, 1983: 276), which leaves open whether inferential or quotative evidentiality exists:

(45) Les jeunes préféreraient que l'employeur se sente responsable de l'avenir qu'il leur prépare (2 December 2000)

The young people would prefer that the employer would feel responsible for their future.

The imperfect appears in similar function in Romance languages today (cf. Labeau and Larrivée, 2005). It enables the opening of another speaker deixis, without the need for naming the other deictic centre. Such uses are particularly striking in journalistic language. The imperfecto forms in the examples (46) to (48) are used to present actions that are completed and determined as far as time is concerned. While here perfective verb forms could also be expected, the journalists use the imperfecto, which allows them to refrain from taking responsibility for the contents and to indicate that they gained the 
conveyed information from observation, from another individual or from own reflection, without however stating an exact source. Often such uses have been declared as narrative imperfecto, which denotes the character of the type of text, but does not contradict the statement of an evidential value:

(46) Al día siguiente de aparecer en las páginas de este diario un artículo suyo sobre la situación de la Universidad, el director del Colegio Mayor Diego de Covarrubias, Diego Mateo del Peral, recibia un oficio del rector de la Universidad Complutense de Madrid en el cual le comunicaba que había propuesto su cese inmediato a la junta de gobierno de la referida universidad. (El País, Educación, 4 August 1997)

The day after the publication of his article on the situation of the university in this newspaper, the director of Colegio Mayor Diego de Covarrubias, Diego Mateo del Peral, received $_{\text {impf }}$ a letter from the Rector of Complutense University in Madrid, in which he informed him that he had proposed his immediate termination as member of the board of directors of this university.

(47) Un soldado croata disparaba ayer con antiaéreos contra posiciones terrestres serbias situadas a 200 metros. NIKOLA SOLIC. AP (La Vanguardia, Ciencia Militar, 2 May 1995)

A Croatian soldier shot with antiaircraft missiles yesterday against Serbian land positions 200 meters away.

(48) Hace algunos días, con el título Cervantes y Shakespeare, salió publicada en su leído diario una erudita relación de la fecunda producción del famoso poeta inglés. Al final se afirma lo siguiente: 'La más alta cumbre de las letras inglesas murió el 23 de abril de 1616. Ese mismo día moría el genio del idioma castellano con Miguel de Cervantes Saavedra'. (El Tiempo, Literatura, 1 June 1990)

A few days ago, a scholarly report appeared in his much-read newspaper. It was entitled 'Cervantes and Shakespeare' and was about the fruitful production of the well-known English poet. The report ended with the conclusion: 'The zenith of English literature died on 23 April 1616. The genius of the Spanish language, Miguel de Cervantes Saavedra, died ${ }_{\text {mp. }}$ on the same day'.

Similarly, uses of the imperfect can be found in other Romance languages, which do not characterise the course of a process without determination and limitation, but rather in which a time-limited and completed process is in view. Here, too, the imperfect reduces the responsibility of the speaker, in this case of the journalist, and refers to an unspecified source:

(49) On y disait que le directeur du corps de ballet ne lui avait vraiment pas laissé de passedroit, [...] (Source: http://www.voir.ca/cinema/fichefilm.aspx?iIDFilm=5045)

One said ${ }_{\mathrm{IMP}}$ there, that the ballet director did not really give her preference. [It was said there that the ballet director did not really let her have a leading role.]

(50) Há já algum tempo alguém evidenciava num artigo do Jornal Terras da Beira, as qualidades da equipa. (Corpus do Português (CDP), n.d., 18 Set 97, A voz que vai morrer em directo)

Already some time ago someone highlighted ${ }_{\text {IMP }}$ the qualities of the team in an article in the newspaper Terras da Beira. 
Particularly striking is the systematic use of the imperfect past tense in stock market reports, where, although concrete numbers and operations are presented, the author does not want to vouch for these and thus refers to these without mentioning the foreign source:

(51) L'action d'Isacsoft perdait 1,5 cent à 35,50 cents mardi après-midi à la Bourse. (http:// www.lapresseaffaires.com/article/20070327/LAINFORMER/70327146/5891/ LAINFORM-ER01)

On Tuesday afternoon the share of Isacsoft lost $1.5 \%$ on the stock market to close at 35.50 cents.

(52) Repsol, que ayer pagaba dividendo movió 23.984 millones de pesetas, y Fecsa, que lo paga hoy 6.310 millones de pesetas. (El Mundo, 9 January 1996, Negocios)

Repsol, which paid out dividends yesterday, moved 2,984 million pesetas, and Fesca, which will pay out today, 6,310 million pesetas.

Imperfect forms of the indicative, which are traditionally not considered to be modalising, may well, therefore, express stance-taking and evidentiality in a complex, covert way. Besides the deixis of the present text producer, they can characterise an additional deixis, that of the source of information. Since German does not have any aspectually marked verb forms, other forms of covert modality must be used, such as polyfunctional modal verbs, ${ }^{6}$ or overt modalisations with the subjunctive or modal particles, such as in the translations of sentence (53):

(53) Diego Mateo del Peral, recibía un oficio del rector de la Universidad Diego Mateo del Peral received ${ }_{\text {IMP }}$ a letter from the rector of the University.

a. Diego Mateo del Peral soll einen Brief des Rektors der Universität erhalten haben.

Diego Mateo del Peral should (MODAL VERB) have received a letter from the rector of the University.

b. Diego Mateo del Peral habe einen Brief des Rektors der Universität erhalten.

Diego Mateo del Peral might have (CONJUNCTIVE) received a letter from the rector of the University.

c. Diego Mateo del Peral erhielt wohl einen Brief des Rektors der Universität.

Diego Mateo del Peral probably received a letter from the rector of the University.

However, since overt modalisations are more explicit and less subtle, they are also often omitted in translations:

d. Diego Mateo del Peral erhielt einen Brief des Rektors der Universität. Diego Mateo del Peral received a letter from the rector of the University.

As the above-mentioned examples show, the means of expression of evidentiality and epistemic modality are language-specific and not easily transferrable from language to language. 


\section{Conclusion}

In our study, we observed a continuum of covert and overt means of expression of evidentiality, in which the possibilities of expression of the Romance languages and German are situated differently. At the one end, means of expression are completely lacking. The fact that the speaker here is referring to a source of information must be derived from the context and the situation. Let us assume for example that someone has read the weather forecast, is standing on the bank of a river and says,

(54) Der Wasserspiegel wird steigen.

The water level is bound to rise.

In this utterance he expresses his conclusion without using special evidential means for this. At the same time the high security of the speaker is conveyed with it. Hence, the commitment of the speaker is greatest when no evidential expressions are used.

The other end is made up of explicit evidential expressions, such as modal verbs used in evidential meaning and evidential adverbials:

(55) Il doit l'avoir fait par pitié.

He must have done it out of pity.

(56) Junto a él, figura una niña, al parecer su hija Margarita, presumiéndose que el cuadro fue pintado en España - en caso de que no sea de Monvoisin - y traído a Chile en los enseres de la familia. (Corpus del Español (CdE), n.d.; Peña Muñoz, Manuel, Ayer soñé con Valparaíso)

Next to him a girl can be seen, apparently his daughter Margarita, whereby it can be assumed that the picture was painted in Spain - if it is not by Monvoisin - and transported to Chile with the household goods of the family.

(57) Esta confianza estaba evidentemente fundada en la disposición general de todos los españoles. (cf. example (8))

This trust is evidently based on the general inclination of all Spaniards.

The modal verb devoir that originally indicates deontic modality is used in perfective contexts to express conclusions. The adverbials can, as in example (56), in fact verbalise the speaker's knowledge from visual perception, or as in example (57), can denote a conclusion from more abstract facts.

Between these two extremes of completely covert and/or overt expression of evidentiality, there are a number of transitions in which at least the following dimensions can be distinguished:

- The expression of evidentiality with means of deontic or buletic modality:

(58) Maria soll ein Buch geschrieben haben.

I heard that Maria wrote a book.

(59) Maria will ein Buch geschrieben haben.

Maria claims to have written a book. 


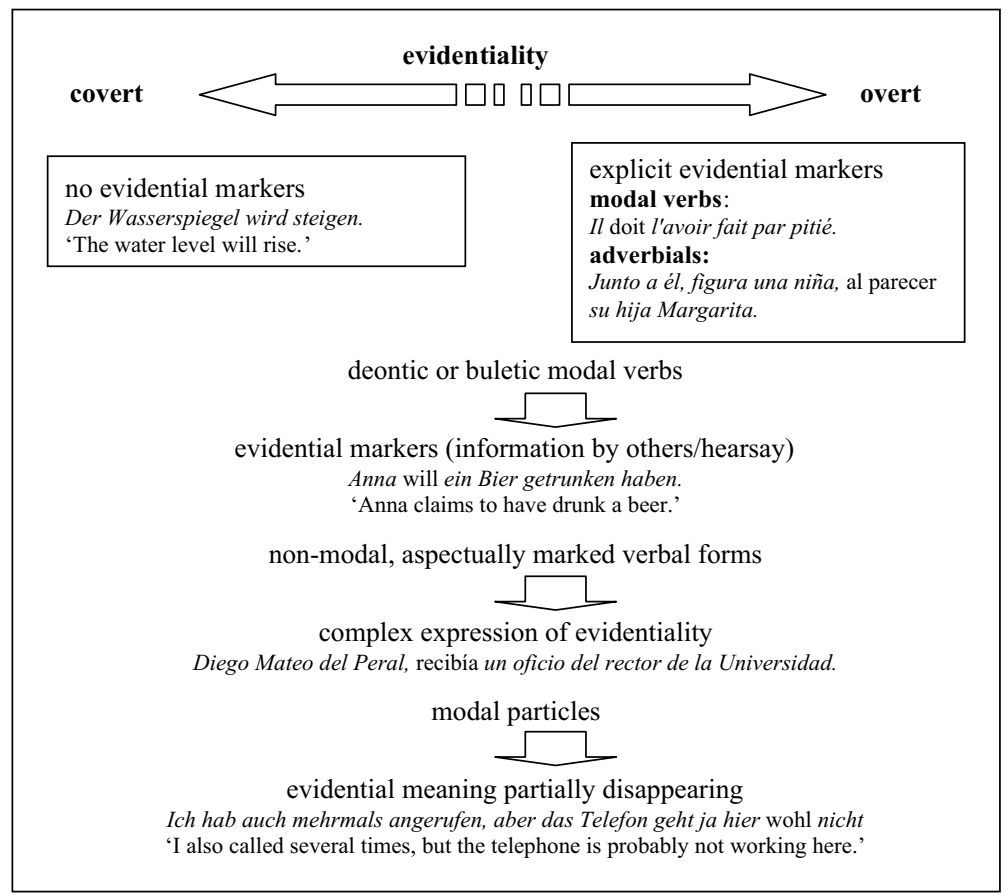

Figure 5. Continuum between overt and covert evidentiality.

- The complex expression of evidentiality and stance-taking with means which until now have not been described as modalising, such as the imperfect tense;

- The disappearance of evidential content in particles should also be taken into account here. ${ }^{7}$ Thus, the evidential content of the modal particle wohl appears in sentence (60) as still present, insofar as reference is made to the origin of the knowledge from several attempts, but wohl often recedes, as in (61) to serve a discourse-organising function, to request a reply:

(60) Ich hab auch mehrmals angerufen, aber das Telefon geht ja hier wohl nicht. (Regener, 2010: 38)

I also called several times, but the phone here is apparently not working.

(61) Was glaubst du wohl? (Regener, 2010: 102)

What do you think?

Already in (60), the modal meaning of wohl appears to be 'hidden' behind the function, giving the listener room to manoeuvre for an answer or an explanation. In the diagram, we attempt to depict the continuum between overt and covert modality (Figure 5).

With regard to the expression of speaker's stance, a reduction in the regress obligation and the commitment of the speaker appear to accompany the evidential marking. 
The more intensely and explicitly the evidentiality of the utterance occurs, the lesser the commitment of the speaker, who can pass on the regress obligation to another deictic instance.

\section{Funding}

This research received no specific grant from any funding agency in the public, commercial or not-for-profit sectors.

\section{Notes}

1. For further studies on evidentiality, see Aikhenvald (2004), Aikhenvald and Dixon (2003), Chafe and Nichols (1986), Dendale and Tasmowski (1994, 2001), Hoff (1986), Ifantidou (2001), Lazard (2001), Mushin (2001), Nuyts (2001), Plungian (2001), Willett (1988), Bybee et al. (1994), De Haan (2001, 2005), Haßler (2001, 2002, 2003, 2004, 2010) and González Vázquez (2006); and see also, with a consciously chosen contrasting term (médiatisation), Guentchéva $(1994,1996)$.

2. A pure aspect language was the Indo-European ancestor language, in which the verbal act was represented as complete and concluded (perfective aspect) or as incomplete and in the process (imperfective aspect). For the expression of aspect correlation, Indo-European had different aspect stems. In the Slavic languages, the aspect correlation exists today primarily from derived verbs (pf. ответить: impf. овечать; pf. прочитать: impf. читать). For further studies on verbal aspect, see Smith (1997), Dahl (2000).

3. Recent works on evidentiality in Romance languages are, for example, Cornillie (2007), Hennemann (2013), Squartini (2001, 2004), Volkmann (2005) and Wachtmeister Bermúdez (2006).

4. For the relationship of aspect and mode, see Abraham (1998, 2008), Abraham and Leiss (2008) and Leiss $(2008,2009)$.

5. For the relationship of deixis and modality, see Haßler and Volkmann (2009).

6. For polyfunctional modal verbs in Germanic languages, see Abraham (1991, 2009) and Abraham and Leiss $(2009,2012)$.

7. For the particles, see Albrecht (1977), Beerboom (1992), Borst (1985), Coniglio (2011), Katelhön (2008), Masi (1996), Meibauer (1994), Molnár (2002), Thurmair (1989), Wegener (1998) and Weydt $(1977,1979)$.

\section{References}

Abraham W (1991) Modalverben in der Germania. In: Iwasaki E (ed.) Begegnung mit dem 'Fremden'. Akten des VIII. Internationalen Germanisten-Kongresses in Tokio 1990 Band 4. München: Iudicium, pp. 109-118.

Abraham W (1998) The aspectual source of the epistemic-root distinction of modal verbs in German. In: Boeder W, Schroeder C, Wagner KH, et al. (eds) Sprache in Raum und Zeit. In memoriam Johannes Bechert. Band 2: Beiträge zur empirischen Sprachwissenschaft. Tübingen: G. Narr, pp. 231-249.

Abraham W (2008) On the logic of generalizations about cross-linguistic aspect-modality links. In: Abraham W and Leiss E (eds) Modality-Aspect Interfaces: Implications and Typological Solutions. Amsterdam and Philadelphia, PA: John Benjamins Publishing Company, pp. $3-13$.

Abraham W (2009) Die Urmasse von Modalität und ihre Ausgliederung. Modalität anhand von Modalverben, Modalpartikel und Modus. Was ist das Gemeinsame, was das Trennende, und was steckt dahinter? In: Abraham W and Leiss E (eds) Modalität. Epistemik und Evidentialität 
beim Modalverb, Adverb, Modalpartikel und Modus. Tübingen: Stauffenburg Verlag, pp. 251-302.

Abraham W and Leiss E (eds) (2008) Modality-Aspect Interfaces: Implications and Typological Solutions. Amsterdam and Philadelphia, PA: John Benjamins Publishing Company.

Abraham W and Leiss E (eds) (2009) Modalität. Epistemik und Evidentialität beim Modalverb, Adverb, Modalpartikel und Modus. Tübingen: Stauffenburg Verlag.

Abraham W and Leiss E (eds) (2012) Covert Patterns of Modality. Cambridge: Cambridge Scholars.

Aikhenvald A (2004) Evidentiality. Oxford: Oxford University Press.

Aikhenvald A and Dixon RMW (eds) (2003) Studies in Evidentiality. Amsterdam and Philadelphia, PA: John Benjamins Publishing Company.

Albrecht J (1977) Wie übersetzt man eigentlich, eigentlich'? In: Weydt H (ed.) Aspekte der Modalpartikeln: Studien zur deutschen Abtönung. Tübingen: Niemeyer, pp. 19-37.

Barnes J (1984) Evidentials in the Tuyuca verb. International Journal of American Linguistics 50: $255-271$.

Beerboom C (1992) Modalpartikeln als Übersetzungsproblem. Frankfurt am Main: Peter Lang.

Biber D and Edward F (1989) Styles of stance in English: Lexical and grammatical marking of evidentiality and affect. Text 9: 93-124. (Special issue on The pragmatics of affect, edited by E Ochs).

Bondarko AV (1984) Teorija grammatičeskogo značenija $i$ aspektologičeskie issledovanija. Leningrad: Nauka.

Borst D (1985) Die affirmativen Modalpartikeln doch, ja und schon. Tübingen: Niemeyer.

British National Corpus (BNC) (n.d.) Available at: http://www.natcorp.ox.ac.uk/

Bybee J, Perkins R and Pagliuca W (1994) The Evolution of Grammar: Tense, Aspect, and Modality in the Languages of the World. Chicago, IL and London: University of Chicago Press.

Chafe W and Nichols J (eds) (1986) Evidentiality: The Linguistic Coding of Epistemology in Language. Norwood, NJ: Ablex.

Comrie B (1976) Aspect. Cambridge: Cambridge University Press.

Coniglio M (2011) Die Syntax der deutschen Modalpartikeln. Ihre Distribution und Lizenzierung in Haupt- und Nebensätzen. Berlin: Akademie Verlag.

Cornillie B (2007) Evidentiality and Epistemic Modality in Spanish (Semi-)Auxiliaries. A Cognitive-Functional Approach. Berlin and New York: de Gruyter.

Corpus del Español (CdE) (n.d.) Available at: http://www.corpusdelespanol.org Corpus do Português (CDP) (n.d.) Available at: http://www.corpusdoportugues.org/ Coseriu E (1976) Das romanische Verbalsystem (ed H Bertsch). Tübingen: G. Narr.

Dahl Ö (ed.) (2000) Tense and Aspect in the Languages of Europe. Berlin: Walter de Gruyter.

De Haan F (2001) The relation between modality and evidentiality. In: Müller R and Reis M (eds) Modalität und Modalverben im Deutschen. Hamburg: Helmut Buske Verlag, pp. 201-206.

De Haan F (2005) Encoding speaker perspective: Evidentials. In: Frajzyngier Z, Hodges A and Rood DS (eds) Linguistic Diversity and Language Theories. Amsterdam: John Benjamins Publishing Company, pp. 379-397.

Dendale P and Tasmowski L (eds) (1994) Les sources du savoir et leurs marques linguistiques. Langue française 102: 1-127.

Dendale P and Tasmowski L (eds) (2001) Evidentialty. Journal of Pragmatics 33: 339-464.

Dessì Schmid S (2010) Modal uses of the Italian imperfetto and the Spanish imperfecto: A comparison. In: Becker M and Remberger E-M (eds) Modality and Mood in Romance: Modal Interpretation, Mood Section, and Mood Alternation. Berlin and New York: Walter de Gruyter, pp. 39-66.

Detges U (2001) Grammatikalisierung. Eine kognitiv-pragmatische Theorie dargestellt am Beispiel romanischer und anderer Sprachen. Habilitationsschrift, Universität Tübingen. 
Diewald G and Smirnova E (2010) Evidentiality in German: Linguistic Realization and Regularities in Grammaticalization (Trends in Linguistics, Studies and Monographs 228). Berlin and New York: Mouton de Gruyter.

Fernández Ramírez S (1986) Gramática española. Vol. 4: El verbo y la oración. Madrid: Arco Libros.

Fleischmann S (1982) The Future in Thought and Language: Diachronic Evidence from Romance. Cambridge: Cambridge University Press.

Frantext (n.d.) Base Textuelle Frantext. Available at: http://www.frantext.fr/

García Fernández L (2004) El pretérito imperfecto: Repaso histórico y bibliográfico. In: García Fernández L and Camus Bergareche B (eds) El pretérito imperfect. Madrid: Gredos, pp. 13-15.

González Vázquez M (2006) Las fuentes de la información: Tipología, semántica y pragmática de la evidencialidad. Vigo: Universidade de Vigo.

Guentchéva Z (1994) Manifestations de la catégorie du médiatif dans les temps du français. Langue française 102: 8-23.

Guentchéva Z (ed.) (1996) L'énonciation médiatisée. Louvain and Paris: Peeters.

Haßler G (2001) Kontrastive und typologische Überlegungen zur epistemischen Modalität in den romanischen Sprachen und im Deutschen. In: Wotjak G (ed.) Studien zum romanischdeutschen und innerromanischen Sprachvergleich. Akten der IV. Internationalen Tagung zum romanisch-deutschen und innerromanischen Sprachvergleich (Leipzig, 7.10.-9.10.1999). Bern; Berlin; Bruxelles; Frankfurt/M.; New York; Oxford; Wien: Peter Lang; Europäischer Verlag der Wissenschaften, pp. 169-184.

Haßler G (2002) Evidentiality and reported speech in Romance languages. In: Güldemann T and Von Roncador M (eds) Reported Discourse. A Meeting Ground for Different Linguistic Domains (Typological Studies in Language 52). Amsterdam and Philadelphia, PA: John Benjamins Publishing Company, pp. 143-172.

Haßler G (2003) Epistemic modality revisited: Evidential functions of lexical and grammatical forms in Romance languages. In: Hajičová E, Kotěšovcová A and Mírovský J (eds) Proceedings of the XVII International Congress of Linguists, Prague, July 24-29, CD-Rom. Praha: Maftyzpress.

Haßler G (2004) El uso evidencial de adverbios modales. In: Cuartero J and Wotjak G (eds) Algunos problemas específicos de la descripción sintáctico-semántica. Berlin: Frank \& Timme, pp. 229-244.

Haßler G (2010) Epistemic modality and evidentiality and their determination on a deictic basis: The case of Romance languages. In: Diewald G and Smirnova E (eds) Linguistic Realization of Evidentiality in European Languages (Empirical Approaches to Language Typology 49). Berlin and New York: De Gruyter Mouton, pp. 223-248.

Haßler G (2012) Indicative verb forms as means of expressing modality in Romance languages. In: Abraham A and Leiss E (eds) Covert Patterns of Modality. Cambridge: Cambridge Scholars, pp. 133-152.

Haßler G and Volkmann G (eds) (2009) Deixis y modalidad en textos narrativos. Münster: Nodus Publikationen.

Hennemann A (2013) A Context-Sensitive and Functional Approach to Evidentiality in Spanish or Why Evidentiality Needs a Superordinate Category. (Potsdam Linguistic Investigations. Bd. 10). Frankfurt am Main: Peter Lang.

Hoff BJ (1986) Evidentiality in the Carib: Particles, affixes and a variant of Wackernagel's Law. Lingua 69: 49-103.

Ifantidou E (2001) Evidentials and Relevance. Amsterdam and Philadelphia, PA: John Benjamins Publishing Company.

Jaffe A (2009) Introduction. The sociolinguistics of stance. In: Jaffe A (ed.) Stance: Sociolinguistic Perspectives. Oxford: Oxford University Press, pp. 3-28. 
Johnstone B (2009) Stance, style, and the linguistic individual. In: Jaffe A (ed.) Stance: Sociolinguistic Perspectives. Oxford: Oxford University Press, pp. 29-52.

Kärkkäinen E (2003) Epistemic Stance in English Conversation: A Description of its Interactional Functions, with the Focus on I Think. Amsterdam: John Benjamins Publishing Company.

Katelhön P (2008) Kleine Wörter: Abtönung und Modalpartikeln. In: Nied M (ed.) Ausgewählte Phänomene zur kontrastiven Linguistik italienisch - deutsch. Milano: Franco Angeli, pp. 212232.

Labeau É and Larrivée P (eds) (2005) Nouveaux développements de l'imparfait. Amsterdam and New York: Rodopi.

Lazard G (2001) On the grammaticalization of evidentality. Journal of Pragmatics 33: 359-367.

Leiss E (2008) The silent and aspect-driven patterns of deonticity an epistemicity (A chapter in diachronic typology). In: Abraham W and Leiss E (eds) Modality-Aspect Interfaces: Implications and Typological Solutions. Amsterdam and Philadelphia, PA: John Benjamins Publishing Company, pp. 15-41.

Leiss E (2009) Drei Spielarten der Epistemizität, drei Spielarten der Evidentialität und drei Spielarten des Wissens. In: Abraham W and Leiss E (eds) Modalität. Epistemik und Evidentialität beim Modalverb, Adverb, Modalpartikel und Modus. Tübingen: Stauffenburg Verlag, pp. 3-24.

Masi S (1996) Deutsche Modalpartikeln und ihre Entsprechungen im Italienischen: Äquivalente für doch, ja, denn, schon und wohl. Frankfurt am Main: Peter Lang.

Meibauer J (1994) Modaler Kontrast und konzeptuelle Verschiebung. Studien zur Syntax und Semantik deutscher Modalpartikeln. Tübingen: Niemeyer.

Molnár A (2002) Die Grammatikalisierung deutscher Modalpartikeln. Frankfurt am Main: Peter Lang.

Mushin I (2001) Evidentiality and Epistemological Stance: Narrative Retelling. Amsterdam and Philadelphia, PA: John Benjamins Publishing Company.

Nuyts J (2001) Subjectivity as an evidential dimension in epistemic modal expressions. Journal of Pragmatics 33: 383-400.

Palmer FR (1986) Mood and Modality. Cambridge: Cambridge University Press.

Plungian VA (2001) The place of evidentiality within the universal grammatical space. Journal of Pragmatics 33: 349-357.

Raible W (1983) Knowing and believing - and syntax. In: Parret H (ed.) De la croyance. Approches épistémologiques et sémiotiques [On Believing. Epistemological and Semiotic Approaches]. Berlin: de Gruyter, pp. 275-291.

Rauniomaa M (2007) Stance markers in spoken Finnish: Minun mielestä and minusta in assessments. In: Englebretson R (ed.) Stancetaking in Discourse: Subjectivity, Evaluation, Interaction. Amsterdam: John Benjamins Publishing Company, pp. 221-252.

Regener S (2010) Der kleine Bruder. Taschenbuchausgabe. München: Goldmann.

Reyes G (1990) Tiempo, modo, aspecto e intertextualidad. Revista Española de Lingüística 20: $17-53$.

Simon-Vandenbergen A-M and Aijmer K (2007) The Semantic Field of Modal Certainty. A Corpus-Based Study of English Adverbs. Berlin: Walter de Gruyter.

Smith CS (1997) The Parameter of Aspect. Dordrecht: Kluwer Academic Publishers.

Squartini M (2001) The internal structure of evidentiality in Romance. Studies in Language 25(2): $297-334$.

Squartini M (2004) Disentangling evidentiality and epistemic modality in Romance. Lingua 114: $873-895$.

Thurmair M (1989) Modalpartikeln und ihre Kombinationen. Tübingen: Niemeyer. 
Volkmann G (2005) Weltsicht und Sprache. Epistemische Relativierung am Beispiel des Spanischen (Tübinger Beiträge zur Linguistik. 481). Tübingen: G. Narr.

Wachtmeister Bermúdez F (2006) Evidencialidad: La codificación lingüistica del punto de vista. Dissertation, Institutionen för Spanska, Portugisiska och Latinamerikastudier, Stockholms Iniversitet, Stockholm.

Weber DJ (1989) A Grammar of Huallaga (Huánuco) Quechua (University of California Publications in Linguistics 112). Berkeley, CA: University of California Press.

Wegener H (1998) Zur Grammatikalisierung von Modalpartikeln. In: Barz I (ed.) Zwischen Grammatik und Lexikon. Tübingen: Niemeyer, pp. 37-55.

Weydt H (ed.) (1977) Aspekte der Modalpartikeln: Studien zur deutschen Abtönung. Tübingen: Niemeyer.

Weydt H (ed.) (1979) Die Partikeln der deutschen Sprache. Berlin: de Gruyter.

Willett T (1988) A cross-linguistic survey of the grammaticalization of evidentiality. Studies in Language 12(1): 51-97.

\section{Author biography}

Gerda Haßler was born 1953, in Werdau, Sachsen. She was educated at Martin Luther University, Halle-Wittenberg, in Romance and Slavic Studies. She earned her Doctorate in 1978 with the thesis, 'On the description of the influence of language on thought in the linguistic theories of the 18th century'. She received her habilitation in 1984, with the work, 'On the development of the semantic concept of value in linguistic theories from the 18th to the 20th century', and a teaching qualification in General Linguistics. Since 1993, she has been Professor of Linguistics and Applied Linguistics at the Institute for Romance Studies at the University of Potsdam. Her research emphasis is on the semantics and functional grammar of the Romance languages, in addition to the history of linguistics. 